\title{
PERSEPSI PETERNAK AYAM PEDAGING (BROILER) TERHADAP KEMITRAAN DI KABUPATEN BEKASI PROVINSI JAWA BARAT
}

\author{
W. Nahraeni ${ }^{1 \mathrm{a}}$, S. Masithoh ${ }^{1}$, I. Maesarah $^{1}$ \\ ${ }^{1}$ Jurusan Agribisnis, Fakultas Pertanian Universitas Djuanda Bogor \\ Jalan Tol Ciawi No. 1 Kotak Pos 35 Bogor 16720 \\ a'Korespondensi: Wini Nahraeni. Telp: 08129682305; E-mail: winisivadevi@yahoo.com
}

\begin{abstract}
This study was aimed at assessing the characteristics of broiler farmers, the perception of broiler farmers of partnership, and the relation between the characteristics and of broiler farmers and their perception of partnership. The study was conducted in May to June 2013 in Bekasi Regency, West Java Province. Forty-six farmers were selected as respondents. Data were subjected to the correlational descriptive analysis. A Spearman rank correlation and coefficient of contingency tests were done. Results showed that respondents were mostly between the age of 35-46 years (47.8\%), males (93.5\%), SMA educated (37\%), partnership farmers $(67.4 \%)$, beginners $(71.7 \%)$, owners of small level farms $(69.6 \%)$, head of medium sized family (71.7\%), and farmers with an income between of Rp1,850,750-54,000,000. Independent farmers gave a very good perception with a perception score of 3.38 and plasma farmers gave a good perception with a perception score of 3.09. Farmers status, farm size, and income were closely related $(\mathrm{P}<0.01)$ to the farmers' perception of partnership. Farmers's experience was found to have significant $(\mathrm{P}<0.05)$ correlation with their perception. Negative correlation was found between farmer characteristics (age, length of farming, number of animals owned, and income) and perception. Apositively weak correlation between number of dependence and farmer perception of partnership was found.
\end{abstract}

Key words: Characteristics, Perception, Partnership

\begin{abstract}
ABSTRAK
Penelitian ini bertujuan untuk mengetahui karakteristik peternak ayam pedaging, persepsi peternak ayam pedaging terhadap kemitraan, dan hubungan karakteristik peternak dengan persepsi peternak. Penelitian ini dilaksanakan pada mulai Mei sampai Juni 2013 di Kabupaten Bekasi Provinsi Jawa Barat. Responden dalam penelitian ini sebanyak 46 peternak. Analisis data meliputi analisis statistik deskriptif korelasional. Pengujian korelasi dilakukan dengan menggunakan uji korelasi rank Spearman (rs) dan koefisien kontingensi (KK). Hasil penelitian menunjukkan bahwa sebagian besar $(47,8 \%)$ peternak berumur antara 35-46 tahun, $(93,5 \%)$ berjenis kelamin laki-laki, tingkat pendidikan responden adalah lulusan SMA $(37 \%)$, sebagian besar $(67,4 \%)$ status peternak adalah peternak mitra, memiliki pengalaman beternak kategori pemula $(71,7 \%)$ lebih dari setengah peternak $(69,6 \%)$ memiliki ternak pada kategori sedikit, lebih dari sebagian peternak memiliki tanggungan keluarga sedang $(71,7 \%)$ dan sebagian besar $(69,6 \%)$ peternak berpendapatan antara 1.850.750-54.000.000 dalam usahaternaknya. Peternak mandiri memberikan persepsi dengan sangat baik dengan skor persepsi sebesar 3,38 dan peternak plasma memberikan persepsi dengan baik dengan skor 3,09 . Status peternak, jumlah ternak, dan pendapatan berhubungan sangat nyata $(p<0,01)$ dengan persepsi peternak terhadap kemitraan sedangkan pengalaman beternak memiliki hubungan nyata $(\mathrm{p}<0,05)$ terhadap persepsi. Terdapat keeratan hubungan yang lemah dengan hubungan yang negatif antara karakteristik peternak (umur, lama beternak, jumlah ternak yang dimiliki, dan pendapatan) dan hubungan yang positif antara jumlah tanggungan keluarga dengan persepsi peternak terhadappelaksanaan kemitraan.
\end{abstract}

Kata kunci : Karakteristik, Persepsi, Kemitraan 


\section{PENDAHULUAN}

Pelaku usahaternak ayam pedaging yang sebagian besar berbentuk peternakan rakyat, banyak yang bekerjasama dengan perusahaan besar dalam bentuk kerjasama kemitraan. Pola kemitraan ini dapat digunakan untuk mengatasi berbagai macam kekurangan yang dihadapi oleh peternak rakyat.

Menurut Firwiyanto

Kemitraan dapat diartikan sebagai jalinan kerjasama dua atau lebih pelaku agribisnis yang saling menguntungkan. Tujuan yang ingin dicapai melalui kemitraan adalah meningkatkan perolehan nilai tambah bagi pelaku kemitraan, meningkatkan pendapatan usaha kecil dan masyarakat, meningkatkan pertumbuhan ekonomi pedesaan, serta memperluas kesempatan kerja. Kemitraan diharapkan menjadi solusi untuk merangsang tumbuhnya agribisnis peternakan terutama mengatasi masalah peternak yang kurang dalam hal permodalan, teknologi, pasar dan manajemen

Bergabung dengan kemitraan ayam pedaging merupakan salah satu cara bagi peternak yang tidak memiliki cukup modal untuk beternak. Namun, pelaksanaan dari atribut kemitraan yang dijalankan belum sesuai dengan harapan peternak. Atribut kemitraan dilihat dari empat indikator kemitraan yang terdiri atas prosedur penerimaan mitra, pelayana teknis budidaya, pelayanan sarana produksi, dan pelayanan pasca panen. Kontrak yang dibuat oleh perusahaan bersifat mengikat dan telah disepakati sebelum kegiatan budidaya dilakukan. Harga yang telah tercantum dalam kontrak, tentunya peternak tidak dapat meminta harga jual panen yang lebih tinggi jika harga pasaran tinggi. Perspesi yang diberikan peternak terhadap kemitraan diharapkan dapat menjadi bahan masukan bagi perusahaan ternak dalam membuat perjanjian kemitraan dengan memperhatikan persepsi peternak.

Sifat peternak yang cenderung tidak mau mengambil resiko dalam berusaha merupakan salah satu alasan mengapa peternak ingin bergabung dalam kemitraan. Melalui persepsi yang diberikan peternak diharapkan dapat terjalin sebuah pengertian bersama antara peternak dengan perusahaan pelaku kemitraan.

Mekanisme kemitraan inti-plasma pada dasarnya harus mempertemukan kepentingan peternak plasma dengan perusahaan inti. Mekanisme kerjasama yang terbentuk harus dapat mewadahi kepentingan masing-masing. Pola kemitraan intiplasma banyak dikembangkan oleh perusahaanperusahaan dengan peternak rakyat seperti yang terdapat di Kabupaten Bekasi. Persepsi yang baik dari peternak terhadap kemitraan nantinya akan mempengaruhi keberhasilan pelaksanaan kemitraan dimasa sekarang maupun di masa mendatang. Peternak akan bersikap mau bekerjasama dengan perusahaan dan saling menanam kepercayaan pada para pelaku kemitraan.

Penelitian ini bertujuan untuk mengetahui karakteristik peternak ayam pedaging di kabupaten Bekasi dan persepsi peternak ayam pedaging terhadap kemitraan yang ada di Kabupaten Bekasi serta hubungan karakteristik peternak ayam pedaging dengan persepsi peternak terhadap pelaksanaan kemitraan di Kabupaten Bekasi.

\section{BAHAN DAN METODE}

\section{Usaha Peternakan Ayam Pedaging}

Ayam broiler atau yang sering juga disebut ayam ras pedaging adalah istilah untuk menyebut strain ayam hasil budidaya teknologi yang memiliki karakteristik ekonomis dengan ciri khas pertumbuhan cepat sebagai penghasil daging (Murtidjo, 2006). Secara rinci Rasyaf (1995) menyebutkan bahwa ayam broiler memiliki pertumbuhan yang sangat pesat pada umur 1-5 minggu dan sudah dapat dipasarkan pada umur 5-6 minggu dengan bobot hidup antara 1,3-1,4 kg. 


\section{Pengertian Kemitraan}

Peraturan Pemerintah Nomor 44 Tahun 1997 yang menerangkan bahwa bentuk kemitraan yang ideal adalah saling menghidupi. Tujuan kemitraan adalah untuk meningkatkan pendapatan, kesinambungan usaha, meningkatkan kualitas sumberdaya kelompok mitra, peningkatan skala usaha, serta menumbuhkan dan meningkatkan kemampuan usaha kelompok maupun usaha mandiri (Sumardjo, 2004).

\section{Pola Kemitraan di Indonesia}

Menurut Keputusan Menteri

Pertanian No. 940/kpts/OT.210/10/97 tentang Pedoman Kemitraan Usaha Pertanian yang merupakan penjabaran dari Undangundang No. 9 Tahun 1995 dan PP No. 44 Tahun 1997, pola kemitraan dibagi kedalam enam kelompok yaitu inti plasma, subkontrak, dagang umum, keagenan, kerjasama operasional agribisnis dan waralaba

1. Inti-plasma, merupakan hubungan kemitraan antara kelompok mitra dengan perusahaan mitra, perusahaan mitra bertindak sebagai inti dan kelompok mitra bertindak sebagai plasma. Dalam pola kemitraan inti plasma, kewajiban bagi kelompok mitra adalah: 1) berperan sebagi plasma, 2) pengelola seluruh usaha bisnisnya sampai dengan panen, 3) menjual hasil produksi kepada perusahaan mitra, 4) memenuhi kebutuhan perusahaan sesuai dengan persyaratan yang telah disepakati. Perusahaan mitra wajib: 1) berperan sebagai perusahaan inti, 2) menampung hasil produksi, 3) membeli hasil produksi, 4) emberi bimbingan teknis dan pembinaan manajemen kepada kelompok mitra, 5) memberikan pelayanan kepada kelompok mitra berupa permodalan /kredit, sarana produksi dan teknologi, 6) mempunyai usaha budidaya pertanian /memproduksi kebutuhan perusahaan, dan 7) menyediakan lahan.
2. Sub kontrak, merupakan kemitraan antara kelompok mitra dengan perusahaan mitra, di dalamnya kelompok mitra memproduksi komponen yang diperlukan oleh perusahaan mitra sebagai bagian dari produksinya dengan tanggung jawab penuh pada perusahaan mitra.

3. Dagang umum, adalah hubungan kemitraan antara usaha kecil dengan usaha menengah atau usaha besar yang berlangsung dalam bentuk kerjasama pemasaran, penyediaan lokasi usaha, dan penerimaan pasokan dari usaha kecil mitra untuk memenuhi kebutuhan yang diperlukan oleh usaha besar atau usaha menengah yang bersangkutan.

4. Keagenan merupakan hubungan kemitraaan yang didalamnya usaha kecil diberi hak khusus untuk memasarkan barang dan jasa usaha menengah atau usaha besar mitranya

5. Kerjasama Operasional Agribisnis, Pola KOA adalah hubungan kemitraan antara petani/kelompok mitra dengan perusahaan mitra, yang di dalamnya petani/kelompok mitra menyediakan lahan, sarana dan tenaga kerja, sedangkan perusahaan mitra menyediakan biaya, modal dan sarana untuk mengusahakan dan membudidayakan suatu komoditi pertanian

6. Waralaba, Berdasarkan PP No. 16 Tahun 1997 dan Keputusan Menteri Perindustrian dan Perdagangan No. 259/MPP/Kep/7/1997 tentang Ketentuan dan Tata Cara Pelaksanaan Pendaftaran Usaha Waralaba ditetapkan bahwa pengertian waralaba adalah perikatan, salah satu pihak diberikan hak untuk memanfaatkan dan atau menggunakan hak atas kekayaan intelektual atau penemuan atau ciri khas yang dimiliki pihak lain dengan suatu imbalan berdasarkan persyaratan yang ditetapkan pihak lain tersebut dalam rangka penyediaan dan atau penjualan barang dan atau jasa. Pengertian pola waralaba dijelaskan 
oleh Pasal 27 Huruf (d) UndangUndang Nomor 9 Tahun 1995 bahwa pola waralaba adalah hubungan kemitraan yang didalamnya pemberi waralaba memberikan hak penggunaan lisensi, merek dagang, dan saluran distribusi perusahaannya kepada penerima waralaba dengan disertai bantuanbimbingan manajemen.

\section{Pengertian Persepsi}

Rakhmat (2004) menjelaskan
bahwa persepsi seseorang tentang obyek, peristiwa atau hubungan-hubungan yang diperoleh dengan menyimpulkan informasi dan menafsirkan pesan. Persepsi adalah pandangan atau sikap terhadap sesuatu hal yang menumbuhkan motivasi, dorongan, kekuatan dan tekanan yang menyebabkan seseorang melakukan atau tidak melakukan sesuatu. Dua faktor yang mempengaruhi proses pembentukan persepsi yaitu faktor struktural dan faktor fungsional. Faktor struktural berasal semata-mata dari sifat rangsangan (stimuli) fisik dan efek-efek syaraf yang ditimbulkannya pada sistem syaraf individu.

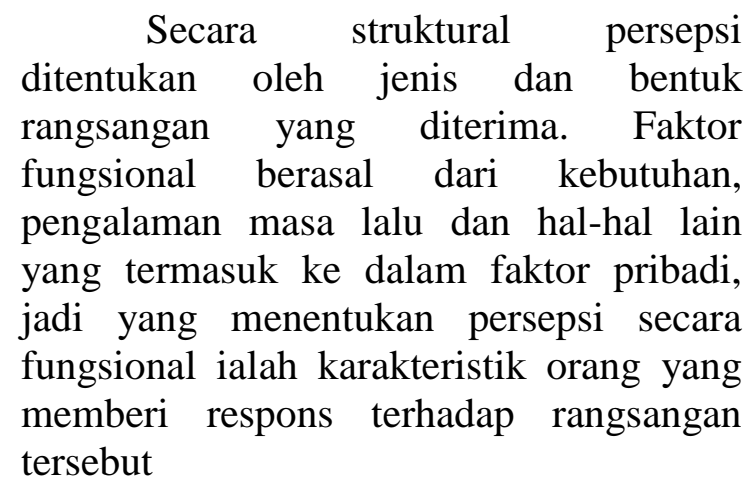

\section{Skala Likert}

Skala Likert digunakan untuk mengukur sikap, pendapat dan persepsi seseorang atau sekelompok orang tentang fenomena sosial. Penelitian ini telah ditetapkan secara spesifik oleh peneliti yang selanjutnya disebut sebagai variable penelitian. Skala Likert yang akan diukur dijabarkan menjadi indikator variabel. Indikator tersebut dijadikan sebagai titik tolak untuk menyusun item-item instrumen yang dapat berupa pernyataan atau pertanyaan (Sugiyono, 2010).

Jawaban dalam setiap item instrumen yang menggunakan skala likert mempunyai tingkatan dari sangat positif sampai sangat negatif yang dapat berupa kata-kata lain. Instrumen penelitian yang menggunakan skala likert dapat dibuat dalam bentuk checklist ataupun pilihan ganda. Kata-kata yang biasa digunakan dalam skala likert adalah :

a. Sangat setuju/Sangat baik

b. Setuju/Baik

c. Ragu-ragu/Tidak baik

d. Tidak setuju/Sangat tidak baik

e. Sangat tidak setuju

\section{Uji Normalitas}

Uji distribusi normal adalah uji untuk mengukur apakah data yang dimiliki terdistribusi normal sehingga dapat dipakai dalam statistik parametrik (statistic inferensial). Uji normalitas digunakan untuk mengetahui suatu variabel normal atau tidak. Normal atau tidaknya sebuah data dilihat dari nilai mean dan standar deviasinya.

Uji normalitas berfungsi untuk membandingkan data berdistribusi normal hingga sesuai dengan kebutuhan penelitian. Data yang terdistribusi normal cocok untuk di olah menggunakan statistik parametrik sedangkan data yang tidak terdistribusi normal lebih baik menggunakan statistik non parametrik untuk mengolah data (Sugiyono, 2010)

\section{Uji Validitas}

Uji validitas adalah suatu langkah pengujian yang dilakukan terhadap isi (content) dari suatu instrumen, dengan tujuan untuk mengukur ketepatan instrumen yang digunakan dalam suatu penelitian. Tujuan uji validitas adalah untuk mengetahui sejauh mana ketepatan dan kecermatan suatu instrument pengukuran dalam melakukan fungsi ukurnya dan agar data yang diperoleh bisa relevan/sesuai dengan tujuan diadakannya pengukuran tersebut (Sugiyono, 2010). 


\section{Uji Reliabilitas}

Uji reliabilitas adalah proses pengukuran terhadap ketepatan (konsisten) dari suatu instrumen penelitian. Pengujian ini dimaksudkan untuk memastikan instrumen yang digunakan dalam penelitian merupakan sebuah instrumen yang konsisten, stabil, dan dependibalitas, sehingga digunakan berkali-kali dapat menghasilkan data yang sama. Tujuan dari uji reliabilitas adalah menujukkan konsistensi skor-skor yang diberikan pada instrumen penelitian.

Pengujian reliabilitas instrumen dapat dilakukan secara eksternal maupun internal. Secara internal reliabilitas instrumen dapat diuji dengan meneganalisis konsistensi butir-butir petanyaan yang ada pada instrumen dengan teknik tertentu. Secara Eksternal pengujian dapat dilakukan dengan testretest (stability),equivalent, dan gabungan dari keduanya.

\section{Analisis Korelasi (Rank Spearman)}

Koefisien korelasi rank spearman digunakan untuk mengetahui ada tidaknya hubungan antara karakteristik peternak dengan persepsi peternak terhadap kemitraan. Nazir (2005) menyatakan jika pengamatan dari dua variable dalam bentuk ordinal, maka derajat korelasi dapat dicari dengan koefisien korelasi rank spearman.

Uji statistik nonparametrik, pengukurannya berupa respon kualitatif atau nilai-nilai pada skala ordinal. Pada skala ordinal, subyeknya diberi peringkat menurut urutan tertentu dan menganalisis peringkat-peringkat tersebut. Pengamatan dua variabel $\mathrm{X}$ dan $\mathrm{Y}$ dalam bentuk skala ordinal, sehingga derajat korelasi dicari dengan koefisien korelasi rank spearman, dengan rumus sebagai berikut:

Keterangan :

$$
R S=1-\frac{6{ }_{i-1}^{n} d i^{2}}{N^{3}-N}
$$

$\mathrm{Rs}=$ Koefisien korelasi

$\mathrm{N}=$ Jumlah sampel penelitian $\mathrm{di}=$ Selisih antara $\operatorname{rank} \mathrm{X}$ dan $\operatorname{rank} \mathrm{Y}$ pada responden ke-i

Secara deskriptif umumnya nilai Rs (Umar, 2005) dikategorikan sebagai berikut:

$0 \leq|\mathrm{rs}| \leq 0,2=$ Berkorelasi sangat lemah

$0,2<\mid$ rs $\mid \leq 0,4=$ Berkorelasi lemah

$0,4<$ rs $\leq 0,6=$ Berkorelasi sedang

$0,6<$ rs $\leq 0,8=$ Berkorelasi kuat

$0,8<\mid$ rs $\leq 1=$ Berkorelasi sangat kuat

\section{Analisis Uji Kontingensi (C)}

Koefisien kontingensi (C) adalah suatu ukuran kadar asosiasi atau relasi antar dua himpunan atribut. Ukuran ini berguna apabila hanya mempunyai informasi kategori skala nominal mengenai satu diantara atribut-atribut. Pengukuran ini digunakan kalau informasi tentang atribut-atribut itu terdiri atas suatu rangkaian frekuensi yang tidak berurut (Siegel, 1997). Keeratan hubungan koefisien kontingensi (C) dapat dilihat berdasarkan nilai-nilai umum korelasi yang juga digunakan dalam korelasi rank spearman (Hasan, 2004). Koefisien kontingensi (C) digunakan untuk melihat hubungan antar variabel dengan rumus pengujian statistik (Siegel, 1997) yang dipakai adalah :

Keterangan :

$$
C=\overline{\frac{X^{2}}{X^{2}+N}}
$$

$\mathrm{C}=$ koefisien kontingensi

$\mathrm{X}_{2}=$ nilai kuadrat

$\mathrm{N}=$ jumlah data

\section{Lokasi dan Waktu Penelitian}

Penelitian ini dilaksanakan di Kabupaten Bekasi. Hal yang menjadi pertimbangan adalah Kabupaten Bekasi merupakan salah satu kabupaten yang menyumbang jumlah populasi dan produksi ayam pedaging pada urutan kelima di Provinsi Jawa Barat. Pengumpulan data dilakukan selama satu bulan (Mei-Juni 2013). 
Metode Pengumpulan Data dan Jumlah Responden

Data yang diperoleh dalam penelitian ini dikumpulkan dan dianalisis secara deskriptif dan kuantitatif. Penelitian ini menggunakan metode sensus dalam pemilihan sampel. Metode sensus yaitu teknik pengambilan sampel dengan cara mengambil seluruh populasi peternak ayam pedaging (broiler) di Kabupaten Bekasi yang berjumlah 46 orang peternak Jumlah peternak ini terdiri atas 15 orang peternak mandiri dan 31 orang peternak plasma sehingga jumlah peternak yang dijadikan responden sebanyak 46 orang peternak. (Dinas Peternakan Kabupaten Bekasi, 2013).

Pengolahan datadilakukan dengan program SPSS versi 16.0 for windows untuk menganalisis hubungan antar peubah. Uji hubungan antar variable menggunakan metode statistik nonparametrik yaitu analisis Korelasi Rank Spearman dan Uji Kontingensi (KK). Persepsi peternak terhadap kemitraan diukur berdasarkan atribut-atribut kemitraan. Atribut-atribut kemitraan dapat dilihat pada Tabel 1.

Tabel 1. Daftar atribut kemitraan peternak ayam pedaging (broiler) di Kabupaten Bekasi

\begin{tabular}{lll}
\hline Periode & No & Atribut \\
\hline Prosedur penerimaan mitra & 1. & Persyaratan bermitra \\
Pelayanan teknis budidaya & 2. & Pemberian modal/kredit \\
& 3. & Frekuensi bimbingan teknis \\
& 4. & Pelayanan dan materi bimbingan \\
& 5. & Respon terhadap keluhan \\
Pelayanan sarana produksi & 6. & Penerapan standar produksi \\
& 7. & Kesesuaian waktu panen \\
& 8. & Penerapan harga kontrak doc \\
& 9. & Kualitas doc \\
& 10. & Harga kontrak pakan \\
Pelayanan pascapanen & 11. & Kualitas pakan \\
& 12. & Harga kontrak obat dan vaksin \\
& 13. & Kualitas obat dan vaksin \\
& 14. & Jadwal pengiriman sarana produksi \\
& 15. & Kesesuaian harga output \\
16. & Pemberian bonus \\
& 17. & Pemberian kompensasi \\
& 18. & Kecepatan pembayaran hasil panen \\
\hline
\end{tabular}

\section{HASIL DAN PEMBAHASAN}

\section{Karakteristik}

Jumlah seluruh responden dalam penelitian ini sebanyak 46 peternak ayam pedaging (Broiler) yang ada di Kabupaten Bekasi. Data karakteristik individu peternak ayam pedaging (Broiler) yang diambil dalam penelitian ini yaitu umur, jenis kelamin, pendidikan, status peternak, pengalaman beternak, dan jumlah tanggungan keluarga, selain itu akan dibahas pula mengenai jumlah ternak serta pendapatan peternak. Karakteristik peternak, jumlah ternak yang dimiliki dan pendapatan dibagi dalam beberapa kelompok berdasarkan nilai terendah dan tertinggi. Karakteristik peternak dapat dillihat pada Tabel 2 . 
Tabel 2. Karakteristik peternak ayam pedaging (Broiler) yang ada di Kabupaten Bekasi

\begin{tabular}{|c|c|c|c|c|}
\hline No & Karakteristik individu & Kategori & $\begin{array}{l}\text { Jumlah } \\
\text { (orang) }\end{array}$ & $(\%)$ \\
\hline \multirow[t]{4}{*}{1.} & Umur & & & \\
\hline & $\leq 34$ tahun & Muda & 16 & 34,8 \\
\hline & $35-46$ tahun & Sedang & 22 & 47,8 \\
\hline & $47-58$ tahun & Tua & 8 & 17,4 \\
\hline \multirow[t]{3}{*}{2.} & Jenis kelamin & & & \\
\hline & & Laki-laki & 43 & 93,5 \\
\hline & & Perempuan & 3 & 6,5 \\
\hline \multirow[t]{5}{*}{3.} & Pendidikan & & & \\
\hline & & Tidak sekolah-tamat SD & 6 & 13,0 \\
\hline & & Tidak tamat SMP-tamat SMP & 8 & 17,4 \\
\hline & & Tidak tamat SMA-tamat SMA & 17 & 37,0 \\
\hline & & Perguruan tinggi (D3-S1) & 15 & 32,6 \\
\hline \multirow[t]{2}{*}{4.} & Status peternak & Mitra & 31 & 67,4 \\
\hline & & Non mitra & 15 & 32,6 \\
\hline \multirow[t]{4}{*}{5.} & Pengalaman beternak (tahun) & & & \\
\hline & $\leq 6$ tahun & Pemula & 33 & 71,7 \\
\hline & $7-13$ tahun & Sedang & 11 & 19,6 \\
\hline & $14-20$ tahun & Berpengalaman & 2 & 8,7 \\
\hline \multirow[t]{4}{*}{6.} & Jumlah tanggungan keluarga & & & \\
\hline & $1-3$ orang & Sedikit & 25 & 19,6 \\
\hline & $4-6$ orang & Sedang & 19 & 71,7 \\
\hline & $7-9$ orang & Banyak & 2 & 8,7 \\
\hline \multirow[t]{4}{*}{7.} & Jumlah ternak (Ekor) & & & \\
\hline & $600-10.398$ & Sedikit & 30 & 69,6 \\
\hline & $10.399-20.199$ & Sedang & 5 & 19,6 \\
\hline & $20.200-30.000$ & Banyak & 11 & 10,8 \\
\hline \multirow[t]{4}{*}{8.} & Pendapatan Usahaternak & & & \\
\hline & $1.850 .750-19.233 .832$ & Rendah & 32 & 69,6 \\
\hline & $19.233 .833-36.616916$ & Sedang & 12 & 26,1 \\
\hline & $36.616 .917-54.000 .000$ & Tinggi & 2 & 4,3 \\
\hline \multirow[t]{4}{*}{9.} & Pendapatan Total & & & \\
\hline & $4.000 .000-31.333 .332$ & Rendah & 21 & 80,4 \\
\hline & $31.333 .333-58.666 .666$ & Sedang & 6 & 15,2 \\
\hline & $58.666 .667-86.000 .000$ & Tinggi & 19 & 4,3 \\
\hline
\end{tabular}

Persepsi Peternak Ayam Pedaging terhadap Kemitraan di Kabupaten Bekasi.

Hasil uji normalitas, validitas, dan reliabilitas menunjukkan bahwa data dalam penelitian ini dapat di uji menggunakan statistic non-parametrik yaitu uji korelasi rank spearman dan uji kontingensi (KK). Hasil Uji normalitas, validitas, reabilitas dapat dilihat pada lampiran 1. Persepsi peternak terhadap kemitraan dilihat dari atribut-atribut kemitraan yang terdiri atas 18 atribut yang dikategorikan menjadi empat indikator yaitu 1) Prosedur Penerimaan Mitra, 2) Pelayanan Teknis Budidaya, 3) Pelayanan Sarana Produksi, dan 4) Pelayanan Pascapanen. Terdapat beberapa atribut kemitraan yang harus mendapat perhatian perusahaan inti dan dilihat kembali serta dipriotitaskan melihat persepsi peternak. 
Persepsi Peternak Mandiri Terhadap Kemitraan di Kabupaten Bekasi

Persepsi peternak mandiri tentang atribut-atribut kemitraan yang harus diprioritaskan dapat dilihat pada Tabel 3 . Berdasarkan Tabel 3, atribut kemitraan yang dianggap harus diprioritaskan dan diutamakan oleh perusahaan perunggasan yang melakukan kemitraan dengan peternak dilihat dari urutan prioritas adalah atribut respon terhadap keluhan, pemberian modal/ kredit, persyaratan bermitra, harga pakan, kualitas pakan, dan harga obat dan vaksin lalu diikuti oleh atribut-atribut kemitraan yang lainnya. Persepsi yang diberikan peternak mandiri terhadap kemitraan di Kabupaten Bekasi diharapkan dapat menjadi masukan bagi perusahaan, pemerintah, dan peternak bahwa peternak masih memiliki persepsi yang ingin mereka sampaikan.

Tabel 3 Atribut Kemitraan yang diprioritaskan Berdasarkan Persepsi Peternak Mandiri

\begin{tabular}{|c|c|c|c|c|c|c|c|c|}
\hline \multirow{2}{*}{ Atribut } & \multicolumn{2}{|c|}{$\mathbf{T P}$} & \multicolumn{2}{|c|}{$\mathbf{P}$} & \multicolumn{2}{|c|}{ SP } & \multirow{2}{*}{$\begin{array}{l}\text { Total } \\
\text { Skor }\end{array}$} & \multirow{2}{*}{ Prioritas } \\
\hline & $\mathbf{F}$ & $\%$ & $\mathbf{F}$ & $\%$ & $\mathbf{F}$ & $\%$ & & \\
\hline \multicolumn{9}{|l|}{ Prosedur penerimaan mitra } \\
\hline - Persyaratan bermitra & & & 6 & 40 & 9 & 60 & 54 & 4,5 \\
\hline - Pemberian modal/ kredit & & & 3 & 20 & 12 & 80 & 57 & 2 \\
\hline \multicolumn{9}{|l|}{ Pelayanan teknis budidaya } \\
\hline - Frekuensi bimbingan & & & 10 & 66,7 & 5 & 33,3 & 50 & 14 \\
\hline - Pelayanan materi bimbingan & & & 14 & 93,4 & 1 & 6,7 & 46 & 17 \\
\hline - Respon thd keluhan & & & 2 & 13,3 & 13 & 66,7 & 58 & 1 \\
\hline - Standar produksi & & & 14 & 93,3 & 1 & 6,7 & 46 & 17 \\
\hline - Waktu panen & 2 & 13,3 & 11 & 73,4 & 2 & 13,3 & 47 & 15 \\
\hline \multicolumn{9}{|l|}{ Pelayanan sarana produksi } \\
\hline - Harga kontrak DOC & & & 7 & 46,7 & 8 & 53,3 & 53 & 8,5 \\
\hline - Kualitas DOC & 2 & 13,3 & 10 & 66,7 & 3 & 20 & 46 & 17 \\
\hline - Harga kontrak pakan & & & 6 & 40 & 9 & 60 & 54 & 4,5 \\
\hline - Kualitas pakan & & & 6 & 40 & 9 & 60 & 54 & 4,5 \\
\hline - Harga obat dan vaksin & & & 6 & 40 & 9 & 60 & 54 & 4,5 \\
\hline - Kualitas obat dan vaksin & & & 8 & 53,3 & 7 & 46,7 & 52 & 12 \\
\hline - Jadwal pengiriman sapronak & & & 8 & 53,3 & 7 & 46,7 & 52 & 12 \\
\hline \multicolumn{9}{|l|}{ Pelayanan pascapanen } \\
\hline - Kesesuaian harga output & 1 & 6,7 & 5 & 33,3 & 9 & 60,0 & 53 & 8,5 \\
\hline - Bonus & & & 8 & 53,3 & 7 & 46,7 & 52 & 12 \\
\hline - Kompensasi & & & 7 & 46,7 & 8 & 53,3 & 53 & 8,5 \\
\hline - Pembayaran hasil panen & & & 7 & 46,7 & 8 & 53,3 & 53 & 8,5 \\
\hline
\end{tabular}

Sumber : Data Primer yang diolah, 2013

\section{Persepsi Peternak Plasma Terhadap Kemitraan di Kabupaten Bekasi \\ Terdapat beberapa atribut} kemitraan yang harus mendapat perhatian oleh perusahaan inti dan dilihat kembali serta dipriotitaskan melihat persepsi peternak. Persepsi peternak plasma tentang atribut-atribut kemitraan yang harus diprioritaskan dapat dilihat pada Tabel 4 .
Berdasarkan hasil penelitian yang dapat dilihat pada Tabel 4, atribut kemitraan yang dianggap harus diprioritaskan dan diutamakan oleh perusahaan perunggasan yang melakukan kemitraan dengan peternak dilihat dari urutan prioritas adalah atribut persyaratan bermitra, respon terhadap keluhan, pemberian kompensasi, standar produksi, kwalitas pakan dan 
diikuti oleh atributatribut kemitraan yang lainnya. Persepsi peternak plasma ini berdasarkan bahwa pelaksanaan dari atribut-atribut tersebut belum sesuai dan masih belum menjadi perhatian perusahaan. Persepsi yang diberikan peternak plasma ayam pedaging (broiler) terhadap kemitraan di Kabupaten Bekasi diharapkan dapat menjadi masukan bagi perusahaan demi terciptanya kemitraan yang baik dan dapat menguntungkan kedua belah pihak

Tabel 4 Atribut Kemitraan yang diprioritaskan Berdasarkan Persepsi Peternak Plasma

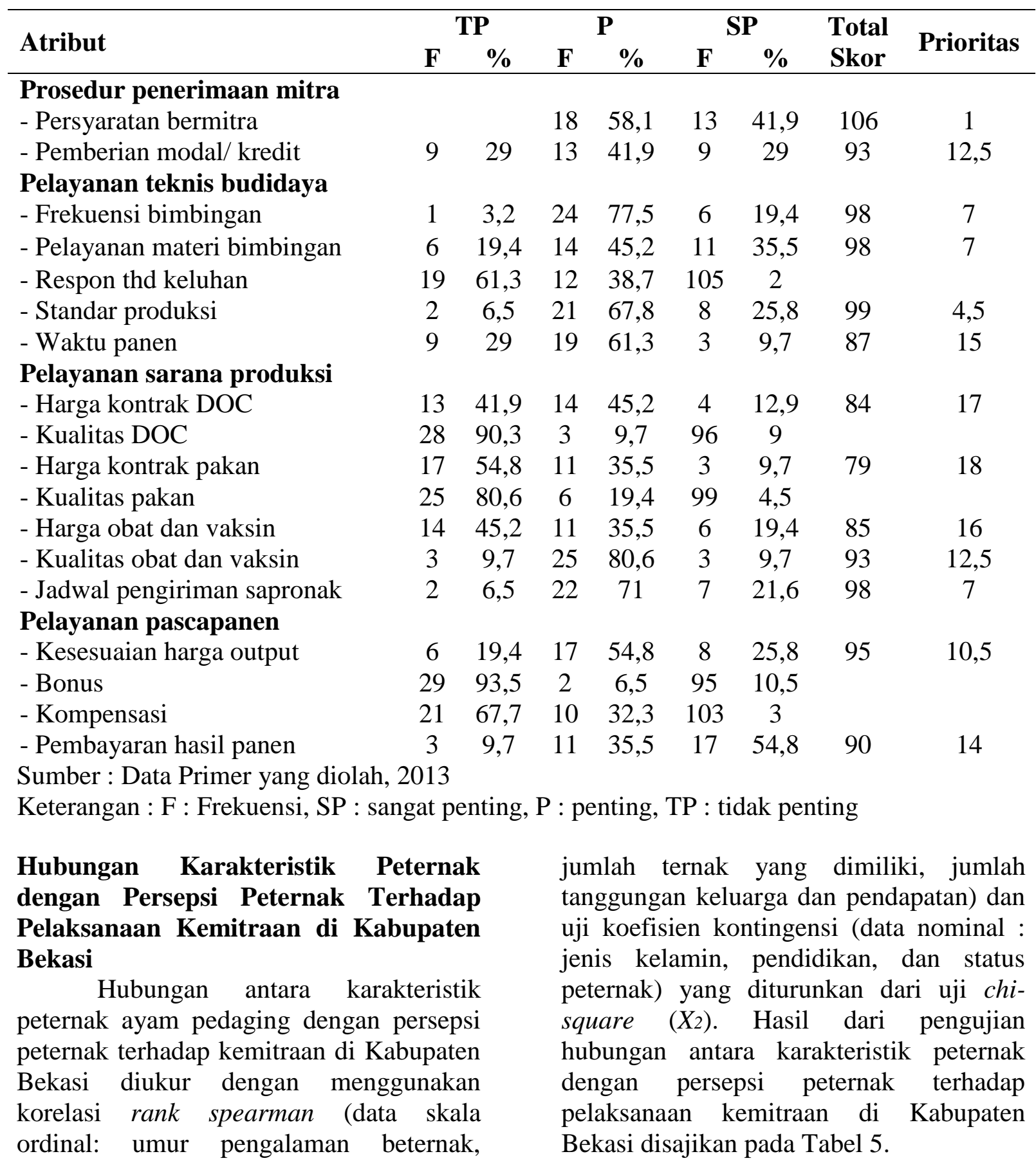


Tabel 5. Koefisien korelasi karakteristik peternak dengan persepsi peternak terhadap kemitraan di Kabupaten Bekasi.

\begin{tabular}{|c|c|c|c|c|c|c|}
\hline \multirow[b]{2}{*}{ Karakteristik } & \multirow[b]{2}{*}{$\begin{array}{l}\text { Uji } \\
\text { Kore } \\
\text { lasi }\end{array}$} & \multicolumn{5}{|c|}{ Persepsi tentang } \\
\hline & & $\begin{array}{c}\text { Prosedur } \\
\text { Penerimaan } \\
\text { mitra }\end{array}$ & $\begin{array}{c}\text { Pelayanan } \\
\text { Teknis } \\
\text { Budidaya }\end{array}$ & $\begin{array}{c}\text { Pelayanan } \\
\text { Sarana } \\
\text { Produksi }\end{array}$ & $\begin{array}{l}\text { Pelayanan } \\
\text { Pascapanen }\end{array}$ & Kemitraan \\
\hline Umur & Rs & $-0,168$ & $-0,279$ & $-0,176$ & -0.215 & $-0,217$ \\
\hline Jenis Kelamin & KK & 0,088 & 0,129 & 0,030 & 0,065 & 0,031 \\
\hline Pendidikan & KK & 0,253 & 0,124 & 0,103 & 0,225 & 0,170 \\
\hline Status Peternak & KK & $0,454 * *$ & 0,235 & $0,440 *$ & 0,196 & $0,438 * *$ \\
\hline Pendapatan & Rs & $-0,292 *$ & $-0,318 *$ & $-0,269$ & $-0,346^{*}$ & $-0,422 * *$ \\
\hline $\begin{array}{l}\text { Jumlah Ternak } \\
\text { Jumlah }\end{array}$ & Rs & $-0,287$ & $-0,302 *$ & $-0,249$ & $-0,342 *$ & $-0,408 * *$ \\
\hline $\begin{array}{l}\text { Tanggungan } \\
\text { Keluarga }\end{array}$ & Rs & 0,011 & 0,031 & 0,076 & 0,0103 & 0,025 \\
\hline $\begin{array}{l}\text { Pengalaman } \\
\text { Beternak }\end{array}$ & Rs & $-0,131$ & $-0,286$ & $-0,417 * *$ & $-0,127$ & $-0,318 *$ \\
\hline
\end{tabular}

Keterangan : $*=$ Nyata pada $\mathrm{p}<0,05 \mathrm{r}_{\mathrm{s}}=$ rank spearman, $* *=$ Sangat Nyata pada $\mathrm{p}<0,01$

$\mathrm{C}=$ Uji kontingensi

$0 \leq|\mathrm{rs}| \leq 0,2=$ Berkorelasi sangat lemah

$0,2<\mid$ rs $\mid \leq 0,4=$ Berkorelasi lemah

$0,4<$ rs $\leq 0,6=$ Berkorelasi sedang

$0,6<$ rs $\leq 0,8=$ Berkorelasi kuat

$0,8<\mid$ rs $\leq 1=$ Berkorelasi sangat kuat

Pengalaman beternak, jumlah ternak yang dimiliki, jumlah tanggungan keluarga dan pendapatan memiliki hubungan yang negatif dengan persepsi peternak terhadap kemitraan. Hubungan negatif ini dikarenakan pengalaman beternak berada pada kategori pemula, jumlah ternak masih sedikit, jumlah tanggungan keluarga berada pada kategori sedikit dan berpendapatan rendah sehingga hubungan yang negatif ini bisa diartikan semakin rendah umur peternak, pengalaman beternak, jumlah ternak, dan pendapatan maka persepsi yang diberikan peternak terhadap kemitraan semakin baik. Hubungan positif antara karakteristik dengan persepsi yaitu jenis kelamin, status peternak, dan jumlah tanggungan keluarga.

Status peternak, jumlah ternak, dan pendapatan berhubungan sangat nyata dengan persepsi peternak sedangkan pengalaman beternak memiliki hubungan nyata terhadap persepsi. Ini menunjukkan bahwa yang berhubungan dengan persepsi peternak terhadap atribut kemitraan adalah status peternak, jumlah ternak, pengalaman beternak dan pendapatan.

\section{KESIMPULAN DAN IMPLIKASI KEBIJAKAN}

\section{Kesimpulan}

Karakteristik peternak sebagian besar peternak berumur antara 34-58 tahun, sebanyak $(93,5 \%)$ berjenis kelamin laki-laki, tingkat pendidikan peternak adalah lulusan SMA (37\%), sebagian besar $(67,4 \%)$ status peternak adalah peternak mitra, memiliki pengalaman beternak kategori pemula $(71,7 \%)$ lebih dari setengah peternak $(69,6 \%)$ memiliki ternak pada kategori sedikit, lebih dari sebagian peternak memiliki tanggungan keluarga sedang $(71,7 \%)$ dan sebagian besar $(69,6 \%)$ peternak berpendapatan antara 1.850.750-54.000.000.

Peternak mandiri memberikan persepsi dengan sangat baik terhadap 
kemitraan dengan nilai rataan skor keseluruhan sebesar 3,38. Peternak plasma di Kabupaten Bekasi secara umum memberikan persepsi dengan baik mengenai kemitraan yang seharusnya berjalan dilihat dari pelaksanaan atributatribut kemitraan dengan skor sebesar 3,09. Peternak mandiri dan plasma yang dijadikan responden memberikan persepsi mereka berdasarkan harapan peternak mandiri dan plasma terhadap kemitraan yang ingin mereka ikuti dan yang telah mereka ikuti dilihat dari pelaksanaan atribut-atribut kemitraan yang terjadi di lapang dan memerlukan adanya perhatian dan prioritas dari perusahaan terhadap atribut-atribut kemitraan.

Atribut kemitraan yang dianggap harus diprioritaskan dan diutamakan dilihat dari urutan prioritas peternak mandiri adalah atribut respon terhadap keluhan, pemberian modal/ kredit, persyaratan bermitra, harga pakan, kualitas pakan, dan harga obat dan vaksin, sedangkan urutan atribut yang harus diprioritaskan menurut peternak plasma adalah persyaratan bermitra, respon terhadap keluhan, pemberian kompensasi, standar produksi, dan kwalitas pakan, dan diikuti oleh atribut-atribut lainnya.

\section{Implikasi Kebijakan}

$\begin{array}{lll}\text { Beberapa implikasi } & \text { kebijakan } \\ \text { yang diharapkan dapat } & \text { membantu } \\ \text { pelaksanaan kemitraan di } & \text { Kabupaten }\end{array}$

Bekasi yaitu :

1. Peternak di Kabupaten bekasi sebanyak $37 \%$ merupakan lulusan SMA dan tidak pernah mendapatkan pendidikan tentang budidaya ayam pedaging ataupun mengetahui tentang kemitraan, pengalaman beternak sebanyak $71,7 \%$ masih berada dalam kategori pemula, saran yang dapat diberikan bahwa peternak mandiri sangat memerlukan adanya penyuluhan mengenai budidaya ayam pedaging ataupun penyuluhan mengenai kemitraan, sedangkan peternak plasma sangat membutuhkan tambahan peran PPL (Penyuluh Lapang) yang dapat membantu mereka dalam hal budidaya ayam pedaging.

2. Prosedur penerimaan mitra yang terdiri atas atribut persyaratan bermitra, pemberian modal dan kredit menurut persepsi peternak mandiri adalah atribut yang sangat penting, karenanya perusahaan kemitraan diharapkan dapat memberi kemudahan untuk persyaratan bermitra bagi calon peternak yang ingin bergabung seperti memudahkan peternak mandiri dalam pengadaan lahan yang kondusif. Sama halnya dengan atribut pemberian modal dan kredit, diharapkan perusahaan kemitraan dapat memberikan modal berupa pinjaman untuk memulai usaha budidaya ayam pedaging dan modal untuk pembuatan kandang untuk budidaya ayam pedaging yang pembayarannya bisa dicicil ketika panen.

3. Peternak palasma memberikan persepsi mereka bahwa pelayanan pasca panen yang terdiri atas atribut kesesuaian harga output, pemberian bonus, pemberian kompensasi, dan kecepatan pembayaran hasil panen merupakan atribut yang kelancaran dalam pelaksanaannya sangat penting dalam kemitraan, karenanya harus adanya kontrak yang jelas mengenai harga jual ayam (harga output) dan harga yang diberikan tidak terlalu murah dari harga pasar, memberikan bonus dan kompensasi kepada peternak plasma, dan kompensasi harus segera diberikan ketika peternak mengalami permasalahan dalam budiaya ayam pedaging, serta perusahaan kemitraan diharuskan bisa mempercepat pembayaran biaya hasil panen maksimal peternak hanya menunggu dalam waktu tiga hari.

4. Atribut kemitraan yang diprioritaskan menurut peternak mandiri dan plasma adalah respon terhadap keluhan yaitu dengan menambah jumlah hari dalam bimbingan yang dilakukan penyuluh lapang (PPL) dalam kunjungannya ke 
kandang, persyaratan bermitra harusnya tidak menggunakan surat tanah dan tidak harus memerlukan lahan yang sangat jauh dari tempat tinggal warga, adanya pemberian kompensasi untuk hasil panen yang tidak memenuhi ketetapan standar produksi dan diharapkan dapat berupa uang, pembayaran hasil panen baiknya lebih dipercepat dengan cara mempercepat perhitungan hasil panen, dan adanya kesesuaian standar produksi yang sudah ditentukan dengan sarana produksi seperti kualitas DOC dan pakan yang diberikan perusahaan.

\section{Daftar Pustaka}

Dinas Peternakan, Perikanan, dan Kelautan Kabupaten Bekasi. 2013. Data Populasi Ternak. http//bekasikab.go.id [6 April 2013]

Firwiyanto M. 2008. Analisis Pendapatan dan Tingkat Kepuasan Peternak terhadap Pelaksanaan Kemitraan Ayam Broiler (Kasus Kemitraan
Peternak Plasma Rudi Jaya Ps Sawangan, Depok (Skripsi). Program Sarjana Eksistensi Manajemen Agribisnis Fakultas Petanian. Institut Pertanian Bogor.

Hasan I. 2004. Analilsis Data Penelitian dengan Statistik. Bumi Aksara, Jakarta

Murtidjo B.A. 2006. Pedoman Ternak Ayam Broiler. Kanisius. Yogyakarta

Nazir M. 2005. Metode Penelitian. Ghalia Indonesia, Jakarta

Rakhmat J. 2004. Psikologi komunikasi. Edisi revisi. Remaja Rosakarya. Bandung

Rasyaf M. 1995. Pengelolaan Usaha Peternakan Ayam Pedaging. Gramedia Pustaka Utama, Jakarta

Siegel S. 1997. Statistik Nonparametrik Penelitian Survai. LP3ES, Jakarta

Sugiyono. 2010. Metode Penelitian Bisnis. Alfabeta, Bandung

Sumardjo. 2004. Teori dan Praktik Kemitraan Agribisnis. Penebar Swadaya, Jakarta 